5. Certain states demand that all nursery stock from other states shall have been fumigated before acceptance under their laws, and it happens that at least one of those states does not demand fumigation of its own stock for interstate shipment, although San José scale is not a stranger. Manifestly the scale conditions in some of our Eastern States is such that fumigation should be required of all stock for interstate shipment. On the other hand, in Iowa, Nebraska, North and South Dakota, Minnesota, and Wisconsin, where there is little or no San José scale, it would be an unnecessary requirement, and these uninfested states have a right to demand greater protection than they have had in the past.

It therefore seems wise that the Federal Horticultural Board should determine the conditions in our states and use their judgment in establishing a quarantine area from which no nursery stock shall enter interstate commerce, without proper and thorough fumigation with hydrocyanic gas.

The above recommendations are to be considered as personal opinions of the writer, resulting from a considerable acquaintance with nursery pests, nursery conditions and practices, and methods of nursery inspection in several sections of the country.

\title{
INSPECTION FOR PLANT DISEASES
}

By Dr. Perley Spadlding

In your inspection of nursery stock you have already become familiar with the various indications of the work of parasitic insects. It, therefore, will be relatively easy for you to separate the symptoms of diseases caused by adverse physiological conditions and fungous parasites from those troubles brought about by the insects. It may be well to briefly consider the various symptoms of plant diseases. The most common symptoms are the following:

Pallor, either in part or of the entire plant, this usually occurring in herbaceous plants and occasionally in the leaves of shrubs. This is caused by certain adverse conditions of the soil.

Spots on the foliage or occasionally upon the younger.twigs of shrubs and upon the main stems of herbaceous plants. These spots may be white, gray, yellow, red, brown, black, or variegated. These are caused by a great number and variety of fungous parasites.

Shot hole of leaves. This usually occurs upon the stone fruits and is caused by the attacks of a fungous parasite killing small circular areas of leaf tissue which fall out and leave round holes.

Wilting, either of entire plants or of parts. This may be caused by 
drought, but there are some very serious fungous diseases which have this symptom.

Death of parts of the affected plant, such as the fire blight of pear and apple twigs.

Dwarfing or atrophy of the affected parts of diseased plants.

Hypertrophy or swelling of the affected parts.

Formation of entire new structures, example ergot.

Mummification. This occurs with a considerable number of the fruit rots.

Change of position of affected part. Example, witches brooms produced by certain fungous parasites.

Destruction of the affected organs, example, grain smuts.

Excrescences and malformations, such as galls, cankers, witches brooms, rosette, and punks or fruiting bodies of the large wood-rotting fungi.

Exudations, consisting of pitch, gum, or slime-flux.

Rotting of fruits, leaves, or of stems in woody-stemmed plants.

In the inspection of nursery stock for diseases, we may classify diseases according to the part of the plant upon which they occur into (1) Diseases of foliage, (2) of twigs, branches and stems, and (3) of the roots.

In general, the diseases of foliage are not serious, except upon seedlings or young nursery stock. These diseases are important, however, with the herbaceous plants. The diseases of the twigs, branches and stems are often very serious with the woody-stemmed plants. Examples of such diseases are:

Killing of twigs on roses, etc., by Botrytis.

Killing of stems of conifers and deciduous trees by Nectria ditissima and $N$. cinnabarina

The chestnut bark disease, which is the most destructive disease of large trees known at the present time.

The various apple cankers

The rose and raspberry stem cankers.

Killing of twigs of stone fruit trees by the gray rot (Monilia).

The various pine-stem blister rusts.

The well-known black knot of cherries.

Our last group, the diseases of roots, are especially serious, not only because they destroy the feeding organs of the plant, but because they cause more or less serious soil infection, oftentimes lasting for several years or longer. Examples of this class of diseases are the well-known crown gall and hairy root of fruit trees, various kinds of root rots, and, finally, but by no means least, root diseases caused by nematodes or eel worms. The latter are especially serious, because soil once infected 
cannot be used for a considerable number of years afterwards for crops of a similar nature. 'A very serious feature also of nematode soil infection is the fact that some species of nematodes have an immense number of food plants. It should also be mentioned that a very serious disease of citrus trees has recently been discovered to be caused by one of the nematodes. Some root diseases to which attention is now very sharply drawn are the various diseases of the potato tuber, which were so prominent in the recent hearing held in Washington to consider the advisability of total exclusion of foreign-raised tubers.

Finally, I may say a word regarding the diseases which are known to occur in imported nursery stock.

It has only recently been discovered that the chestnut bark disease is a native of China, and was undoubtedly imported into this country.

The white pine blister rust is known to have been imported directly from Europe.

The potato wart and potato powdery scab occur upon imported potatoes.

Crown gall and hairy root have been found upon a considerable number of different fruit trees and also upon several of the ornamental shrubs.

Azaleas have been found quite generally affected with leaf galls caused by an Exobasidium.

Rhododendrons in one case were found infected with a tiny leaf gall caused by a Synchytrium.

Miscellaneous leaf spots have been found upon a number of different species of shrubs.

Clematis has been found affected with root rot.

Pæonia, lilac, and rose leaves and stems have been found with the small black sclerotia of the fungus Botrytis vulgaris, which develop in transit.

Finally may be mentioned the finding of the fruit rot fungus Glomerella rufomaculans, fruiting on avocado seeds; apparently an entirely new observation for this fungus.

In order that I may be familiar with what you are finding in different parts of the country, I have asked you to forward to me specimens of diseased plants which you may encounter in your inspections. Free and cordial coöperation in this regard will do much to make efficient my own efforts to help you solve some of the knotty problems in connection with inspection for fungous plant diseases.

An exhibit was made of diseased plants illustrating various symptoms of disease. 